\title{
In-vitro analysis of the susceptibility of Salmonella typhi to Chloramphenicol and leaf extracts of Cassia occidentalis
}

\author{
Article by Otorkpa Oche Joseph ${ }^{1}$, Farouq A. Ahamed ${ }^{2}$, Stephen Emmanuel ${ }^{3}$ \& \\ Mathew Idoko ${ }^{4}$ \\ ${ }^{1,2}$ Usmanu Danfodiyo University, Sokoto State \\ ${ }^{3}$ Kogi State University, Anyigba, Kogi State \\ ${ }^{4}$ Texila American University, Guyana \\ E-mail: ochejoseph@yahoo.com
}

\begin{abstract}
In-vitro analysis of the susceptibility of Salmonella typhito Chloramphenicol and leaf extracts of Cassia occidentalis was conducted using ethanol, ether, hot and cold water extracts. Of these leaf extracts, Salmonella typhi was only found to be sensitive to the ether extracts at a concentration of $40,60,80,100$, and $120 \mathrm{mg} / \mathrm{ml}$ with zones of inhibition (mm) of 4.0, 3.0, 5.0, 4.0, and 4.0 respectively. It was however sensitive to two brands of chloramphenicol A and B with zones of inhibition 15.0, 13.0, 14.0, 23.0, and 25.0. 20.0, 18.0, 16.0, 21.0 and 20.0 respectively at various concentrations. The result of this study showed that chloramphenicol had higher in vitro activity against Salmonella typhi compared to the leaf extract regardless of the extraction method employed.
\end{abstract}

Keywords: Cassia occidentalis, Chloramphenicol, Salmonella typhi, Susceptibility, Leaf extracts

\section{Introduction}

Salmonella typhi is a gram negative rod shaped motile non spore forming bacterium that causes typhoid fever, humans become infected by ingesting food or untreated water containing the organism Once ingested they are taken up by the mononuclear phagocytes whose job it is to engulf and destroy the invading bacteria. However, in some cases the bacteria evade the phagocytes and multiply within the cells and spill into the blood steam where they produce symptoms of the disease. Drugs such as Chloramphenicol, Ampicillin ciprofloxacin and ceftriaxone are being used for the treatment of this condition. Worthy of note is the fact that Chloramphenicol has been the drug of choice for typhoid fever for more than 40 years in regions of the world where Salmonella typhi remains susceptible to the drug. (Butler 1999)

Cassia occidentalis is an erect, shrubby medicinal plant belonging to the family Leguminosea and Genus Cassia (Feng 1962). Since the advent of the 19th century, the flowers, leaves, seeds and roots of Cassia occidentalis have been used in traditional medicine in the rain forest and other areas where the plant grows. This plant is widely used in the treatment of malaria, poultice, and typhoid fever in the northern parts of Nigeria especially Sokoto located in the North western part of the country. According to Odikamnoro et al. (2015), the use of local herbs in the form of concoction and decoction in treatment of various infections has been a common practice and about $75 \%$ of the people living in the rural areas depend on this practice.

As a result of the increasing cases of resistance to chloramphenicol and the fatal side effect especially bone marrow depression and fatal blood dyscrasias posed by the administration of the drug and the reports of promising results obtained by traditional and alternative medical practitioners using extracts from the plant it became necessary to carry out this research on Cassia occidentalis. 
Texila International Journal of Clinical Research

Volume 4, Issue 1, Jun 2017

\section{Materials and method}

The samples were collected as described by Deeni and Aishatu (1994) and Cheesbrough (2000).

\section{Sample collection}

Plant materials were collected from local farms in Dundaye village near the permanent site of the Usmanu Danfodio University Sokoto, Nigeria. The plant was identified in the Botany unit of the Usmanu Danfodio University Sokoto. The leave were plucked and sundried for two days and later grounded into powder using pestle and mortar. The powder was sieved with an eighty micron sized aperture. The chloramphenicol capsules were obtained from Freedom Pharmacy and French Afrique Pharmacy Sokoto

\section{Test organism}

The test organism (clinical isolates) were obtained from Microbiology laboratory of Usman Danfodio University Teaching Hospital, Sokoto.

\section{Processing of plant leaves}

\section{Extraction procedure}

Cold water extract: two gram of the powder was weighed using a weighing balance and put into a beaker constraining one hundred milliliters $(100 \mathrm{ml})$ of distilled water left overnight. Similarly procedure was repeated for $3 \mathrm{~g}, 5 \mathrm{~g}, 10 \mathrm{~g}$, and $15 \mathrm{~g}$ of the powder the suspension was then filtered with funnel and cotton wool to obtain the extract. The extract was allowed to stand until the volume reduced to $10 \mathrm{ml}$.

\section{Hot water extract}

Two grams of the powder was weighed using a weighing balance and put into a beaker containing one hundred milliliters $(100 \mathrm{ml})$ of distilled water and boiled on a hot plate. The boiled suspension was then left overnight. The same procedure was carried out using $3 \mathrm{~g}, 5 \mathrm{~g}$, $10 \mathrm{~g}$, and $15 \mathrm{~g}$ of the powder, the suspension was then filtered using cotton wool and funnel. The extract was then concentrated to $10 \mathrm{ml}$ by boiling.

\section{Ethanol extract}

Ten gram of powder was weighed using a weighing balance. The powder was then dispense into thimble which was place in the soxhlet extractor containing two hundred millilitres of the solvent (Ethanol).

The soxhlet extractor was then operated until colour change became visible indicating that the extraction process has commenced this continued until no further change in the colour of the solvent was visible and thus marked the end of the extraction process.

The ethanol was separated from the extract by heating and condensation of the ethanol into the extractor and collection of the extract in a $10 \mathrm{ml}$ beaker. The same procedure was repeated for 15g, 20g, 25g, and 30g.

\section{Ether extract}

Ten (10) grams of the powder was weighed using a weighing balance. The powder was then dispensed into the thimble, which was then placed in the soxhlet extractor containing two hundred milliliters $(200 \mathrm{ml})$ of the solvent (ether). The soxhlet extractor was then operated until colour change became visible indicating the commencement of the extraction process.

This continued until there was no further change in colour of the solvent, which marked the end of the extraction process.

The ether was then separated from the extract by heating and condensation of ether into extractor and the collection of the extract in a $(10 \mathrm{ml})$ beaker.

The same procedure was repeated for $15 \mathrm{~g}, 20 \mathrm{~g}, 25 \mathrm{~g}$ and $30 \mathrm{~g}$. 


\section{Preparation of media}

The media were prepared according to manufacturer's specifications

\section{Preparation of disc}

Disc of about $6.0 \mathrm{~mm}$ in diameter were punched from what man filter paper No. 1 and sterilized in a hot air oven at 160 oc for 1 hour.

The antibiotics solutions were made using sterile distilled water. The disc were then put into the varying concentrations of the antibiotic solution and extract and allowed to soak all the liquid after which they were air dried.

\section{Sensitivity test}

Discs diffusion techniques was employed as described by chees borough (2000), Edward (1979), Lacey (1984), Deeni and Aishatu (1994).

\section{Results}

The cold water, hot water and ethanol extracts of Cassia occidentalis showed no activity in-vitro on clinical isolates.

Tables 1. Shows the susceptibility of Salmonella typhi in zones of inhibition (mm) obtained against different concentrations of ether extract of Cassia Occidentalis.

\begin{tabular}{|l|}
\hline Concentration $(\mathrm{mg} / \mathrm{ml})$ Zones of inhibition $(\mathrm{mm})$ \\
\hline $40 \mathrm{mg} / \mathrm{ml} 4.0$ \\
\hline $60 \mathrm{mg} / \mathrm{ml} 3.0$ \\
\hline $80 \mathrm{mg} / \mathrm{ml} 5.0$ \\
\hline $100 \mathrm{mg} / \mathrm{ml} 4.0$ \\
\hline $120 \mathrm{mg} / \mathrm{ml} 4.0$ \\
\hline
\end{tabular}

$250 \mathrm{mg} / 25 \mathrm{ml}$ of chloramphenicol was used as control

The clinical isolates were highly susceptible to the antibiotic (chloramphenicol).

Table 2. Shows the susceptibility of Salmonella typhi in zones of inhibition (mm) obtained against different concentration of brand A of chloramphenicol.

\begin{tabular}{|l|}
\hline Concentration (mg/ml) Zones of inhibition $(\mathrm{mm})$ \\
\hline $250 \mathrm{mg} / 10 \mathrm{ml} 15.0$ \\
\hline $250 \mathrm{mg} / 20 \mathrm{ml} 13.0$ \\
\hline $250 \mathrm{mg} / 30 \mathrm{ml} 14.0$ \\
\hline $250 \mathrm{mg} / 40 \mathrm{ml} 23.0$ \\
\hline $250 \mathrm{mg} / 50 \mathrm{ml} 25.0$ \\
\hline
\end{tabular}

The clinical isolates were also susceptible to Brand B of the antibiotic

Table 3. Shows the susceptibility of Salmonella typhi (zones of inhibition) (mm) obtained against different concentration of brand B of chloramphenicol

\begin{tabular}{|l|}
\hline Concentration $(\mathrm{mg} / \mathrm{ml})$ Zones of inhibition $(\mathrm{mm})$ \\
\hline $280 \mathrm{mg} / 10 \mathrm{ml} 20.0$ \\
\hline $250 \mathrm{mg} / 20 \mathrm{ml} 18.0$ \\
\hline $250 \mathrm{mg} / 30 \mathrm{ml} 16.0$ \\
\hline $250 \mathrm{mg} / 40 \mathrm{ml} 21.0$ \\
\hline $250 \mathrm{mg} / 50 \mathrm{ml} 20.0$ \\
\hline
\end{tabular}


Texila International Journal of Clinical Research

Volume 4, Issue 1, Jun 2017

\section{Discussion}

The result of the susceptibility patterns of chloramphenicol antibiotic showed that the antibiotic is still more active than the plant extract indicated by the 25 millimeter (mm) zone of inhibition. This agrees with the set standards according to the National Committee for Clinical Laboratory Standards, NCCLS (1997) which sets $\geq 21 \mathrm{~mm}$ for susceptibility.

The higher zone of inhibition observed in the chloramphenicol indicates that despite the emergence of resistant strains the antibiotic is still useful in the treatment of typhoid fever and other complications due to Salmonella (Harold and Fu, 1980). The report by Deeni and Aishatu (1994) supported the emergence of resistant strains of the microorganisms to chloramphenicol in which most of the bacteria isolated in Murtala Muhammed teaching hospital, Kano, showed high susceptibility to chloramphenicol when compared to other drugs.

On the other hand, the inactivity of the 3 extracts cold : water, hot water and ethanol extracts on the clinical isolates can be attributed to many factors one of which may be that the plant could only be active In vivo when conjugated with other biomolecules, but not In vitro where it is in direct contact with the test organism as reported by Roman et al. (1995) and Koh et al. (2002) in which it was report that cineole obtained from a tree Melaleuca alternafolia showed no activity in vitro against Staphylococcus aureus, Staphylococcus epidermidis And Propionibacterium acnes although it was reported that same cineoles was active in vivo in treatment of acne and other complication due to these organisms.

\section{Conclusion}

In conclusion, it is clear from the results obtained that although the ether leaf extract of Cassia occidentalis showed little activity against Salmonella typhi comparatively chloramphenicol had a higher in-vitro activity against the organism as evidenced by the wider zone of inhibition recorded.

\section{References}

[1]. Butler, T., Sridhar, C. B., Daga, M. K., Pathak, K., Pandit, R. B., Khakhria, R.\& Johnson, R. B. (1999). Treatment of typhoid fever with azithromycin versus chloramphenicol in a randomized multicentre trial in India. Journal of Antimicrobial Chemotherapy, 44(2), 243-250.

[2]. Cheesbrough, Monica (2000); District Laboratory Practice in Tropical Countries Cambridge University Press Cambridge. 182-186

[3]. Coyle, M. B. (2005). Manual of antimicrobial susceptibility testing. American Society for Microbiology.40-41

[4]. Deeni, Y.Y. and Aishatu M. T., (1994) Antimicrobial Susceptibility of Clinical Isolates of Enteric Bacteria in Kano, Nigeria. Orient Journal of Medicine. (1\&2); 1-4

[5]. Edward, M.J. (1979): Bacterial Susceptibility Testing and Assays in Clinical Diagnosis and management pp. 103-106

[6]. Feng, P. (1962) Pharmacological Screening of some West Indian Medicinal Plants. Journal of Pharmacology 14 556-561

[7]. Harold, C.N and F.U.P.K. (1980) Invitro activity of chloramphenicol and Thiamphenical Analysis. Journal of Antimicrobial Agents and chemotherapy 18(2):2-3

[8]. Hussain, (1991) Hausa Medical Plant. A publication of Gaskiya Medical Services 2: 13-14

[9]. Katzung, G. (2000) Basic and Clinical Pharmacology 5th edition Lange McGraw-Hill New York. Pp. 187-188

[10]. Koh, K.J., Pearce, AL, Marshman G., Finlay Jones J.J., (2002) Tea Oil reduces histamine induced skin inflammation. The British Journal of Dermatology 146 (6): 12 12-1217

[11]. Lacey, R. W. (1984) Antimicrobial resistance in bacteria. (Staphylococcus aureus and Streptococci) British Medical Bulletin 40 page (66-83)

[12]. Parker M. J. and Stuck V. A. (1982) Microbiology for Nurses. ELBS English Language Books Society) London. Pp. 147.

[13]. Mohammed (1996)Comparative Study of Cassia occidental sand chloramphenicol. pp 2-21 
[14]. Odebiyi, O. O. and Sofowara, E. A. (1974) "Photochemical Screening of $2{ }^{\text {nd }}$ Nigerian Medicinal Plants”. OAU/STRC. Inter-African symposium on traditional pharmacopoeia and African medicinal Plants OUA/STRC publication No. 115, Lagos Pp. 216

[15]. Odikamnoro O. O., Uhuo C. A., Ikeh I. M., OgijiE. D., Ibiam, G.A, Azi, S.o., Akpam L. J. and Okoh N. F (2015) Antibacterial activities of two medicinal herbs on Salmonella typhi isolates in Abakaliki, Ebonyi State, Nigeria: Improvement to herbal medicine. Journal of Bacteriology Research, Vol. 7(2), pp. 14-18, DOI: 10.5897/JBR2014.0130.

[16]. Patney, N. (1978) A preliminary Report on the role of Liv-52-an Indigenous Drug in Serum B Hepatits Australia Antigen Positive) Cases probe 172. pp 132-142.

[17]. Presscott L.M, Harley J.P. and Klein D.A. (2002) General Microbiology McGraw Hill New York5th Edition pp 774-778.

[18]. Roman, A., wire R. and Bloomfield S.S.E (1995) antifungal effects of Teatreeoil and its major Components on Staphylococcus aureus, Staphylococcus epidermidis and Propronibacterium acnes. Letters in Applied Microbiology 21(4):222.

[19]. Sadique, J. biochemical modes of action of Cassia occidentalis and Cardiospermum halicacabum in inflammation. Journal of Ethanopharmacol. 14:556-557 